\title{
A Description of Fish Assemblages in the Black Coral Beds off Lahaina, Maui, Hawai ${ }^{\prime}{ }^{1}$
}

\author{
Raymond C. Boland ${ }^{2,3}$ and Frank A. Parrish ${ }^{2}$
}

\begin{abstract}
A series of scuba dives surveyed patches of black corals and their associated deep-reef fish community in the channel waters (50-73 m depth) of Maui, Hawai'i. Most of the corals were identified as Antipathes dichotoma and averaged $76 \mathrm{~cm}( \pm 0.37)$ in height. Forty fish taxa were surveyed in the patches. Only Oxycirrbites typus was found exclusively within these coral trees. Sixty percent of the fish taxa surveyed were observed to frequent and pass through the coral branches. However, only four fish species were documented to reliably take shelter in the coral branches when evading an approaching diver. An archival video monitored movement patterns of fishes around a cluster of black coral trees for a 60-hr period. During daylight hours Dascyllus albisella, Centropyge potteri, Forcipiger flavissimus, Aulostomus chinensis, and Canthigaster jactator were observed to be the routine users of the coral patch, but only Dascyllus albisella and Centropyge potteri appeared to be resident to specific trees. At night Sargocentron sp. were observed feeding around the base of the coral trees, and Heniochus diphreutes dropped from their daytime position high in the water column to hide in the tree branches throughout the night. These observations indicate that black coral trees are used by many fishes as a general form of habitat, and if the coral trees are the largest relief feature at a site, their removal will likely impact the fish assemblage.
\end{abstract}

Recent CONCERn about trawl fisheries damaging deepwater coral beds has spurred considerable interest in understanding the ecological importance of deepwater corals to the marine community (Auster et al. 1996, Freese et al. 1999). The fragile structure of the coral colonies, their patchy distribution, and their slow growth predispose this set of taxa to human impacts. The shallowest deepwater coral species, black corals (Antipathes spp.), are known to occur worldwide and are perhaps the most studied because of their relative accessibility and value as raw material

\footnotetext{
${ }^{1}$ Manuscript accepted 9 August 2004.

${ }^{2}$ Pacific Islands Fisheries Science Center, National Marine Fisheries Service, 2570 Dole Street, Honolulu, Hawai'i 96822-2396.

${ }^{3}$ Phone: 808-983-5716; fax: 808-983-2902, e-mail: Raymond.Boland@noaa.gov.
}

Pacific Science (2005), vol. 59, no. 3:411-420

(C) 2005 by University of Hawai'i Press

All rights reserved for the jewelry trade (Grigg 1964, Gonzalez et al. 1997, Romero 1997). Despite this, the bulk of black coral resides at depths beyond conventional scuba diving, it is hidden from the public's general awareness and is difficult to study.

In Hawai'i black coral has been a focus of persistent low-level attention since 1958 when independent divers began harvesting black corals and selling them as raw material to the jewelry industry (Grigg 1965). The fishery has always been composed of a small number of divers, and its primary form of regulation has been harvest size limits. State and federal regulations from 1978 to 1998 required that trees either had a base diameter greater than 1 inch $(26 \mathrm{~mm})$ or a height of 48 inches $(1.2 \mathrm{~m})$. In 1998 the state regulations were changed to allow harvesters who had participated in the fishery for $5 \mathrm{yr}$ or more to harvest trees with $3 / 4$ inch-diameter bases (19 $\mathrm{mm})$ or 36 inches $(0.9 \mathrm{~m})$ tall. This allowance was also added into the federal regulations in 1999. New harvesters were required to adhere to the former state and federal rules. 
Black coral research in Hawai'i has included studies to determine its ecological conditions (Grigg 1965), fishery science parameters (Grigg 1993, 2001), and conservation technology (Montgomery 2002). Little attention has been directed at describing the coral's associated fish community or evaluating the importance of black coral trees as shelter for deep-reef fishes. Almost all of the available data on Hawaiian black coral come from the channel waters between Maui and the islands of Moloka' $i$ and Lāna'i. The corals occupy a 40 - to $80-\mathrm{m}$ submerged platform that interconnects the islands and presents a number of areas with the high-flow characteristics that black corals require to colonize successfully (Grigg 1965). Many of the black coral species in the Islands are as yet unidentified, but the three taxa that compose the fishery are commonly referred to as Antipathes dichotoma, Antipathes grandis, and Antipathes ulex. These coral colonies or "trees" grow to over $3 \mathrm{~m}$ in height and support many filamentous branches forming a substantial bush that intuitively seems to be good cover for fishes. Given the prolonged coral fishery in the region and the questions about the importance of deepwater corals as fish habitat, a series of fish and coral surveys was conducted in the channel waters off Maui. In this paper we present data from those surveys that detail the fish community and identify any obvious associations between fishes and the coral trees.

\section{MATERIALS AND METHODS}

\section{Diver Surveys}

Surveys were conducted in the channel waters off southeastern Maui from the NOAA ship Townsend Cromwell in August 2000 and 2001 (Figure 1). A real-time remote camera was used from the ship to inspect the general areas known to support black coral. Recent high-resolution National Ocean Service bathymetry data (U.S. Geological Survey Water Resources Investigations Report 004046) identified areas of steep topography to survey. When sizable patches of black coral were encountered, the position was marked and divers were deployed to conduct a detailed survey of the bed. The divers breathed helium-based gas mixtures and worked during slack tide on the bottom between 50 and $73 \mathrm{~m}$ for $25 \mathrm{~min}$ per dive. All dives started at the deepest depth $(73 \mathrm{~m})$, and each of the trees was evaluated as the divers progressed shallower. One of the divers collected coral tree size-structure data and the other recorded the trees' fish assemblages. A tape measure was used to measure the tree height in centimeters, and calipers were used to measure the thickness of the tree stem at its base. A standardized video methodology was employed to record fish assemblages of coral trees. The video camera was centered on each coral tree at a distance of $3 \mathrm{~m}$ and then slowly moved up to the tree, recording which fishes fled and which stayed with the tree. Observations from the video were then entered into a relational database. Noted were the fish species, descriptions of the trees (live/dead, height, presence of Caijoa riisei), and finally the reaction of fishes to the approaching diver. The diver collecting fish assemblage data was able to survey a number of trees in addition to those measured for size structure.

\section{Archival Video}

At one site an independent, computercontrolled archival camera was deployed for $60 \mathrm{hr}$ to document changes in fish assemblages around black corals without the presence of divers. The camera was deployed at $52 \mathrm{~m}$ on the flank of a conical pinnacle (area $\sim 8,000 \mathrm{~m}^{2}$ ) that rose from the sand bottom of a solution basin $(73 \mathrm{~m})$. The only source of relief was more than 90 black coral trees, all of which had been surveyed by divers before the camera deployment. The camera was positioned to survey three coral trees in a 4$\mathrm{m}^{2}$ area and was programmed to record video for $3 \mathrm{~min}$ after every $20 \mathrm{~min}$. The camera was equipped with an infrared element and emitter to record fish activity at night. The recovered videotape was scored for fish species, relative speed of water flow (based on movement of tree branches and drift of particulate matter), and whether fishes appeared transitory or residential to trees. Transitory fishes 


\section{MAIN HAWAIIAN ISLANDS}

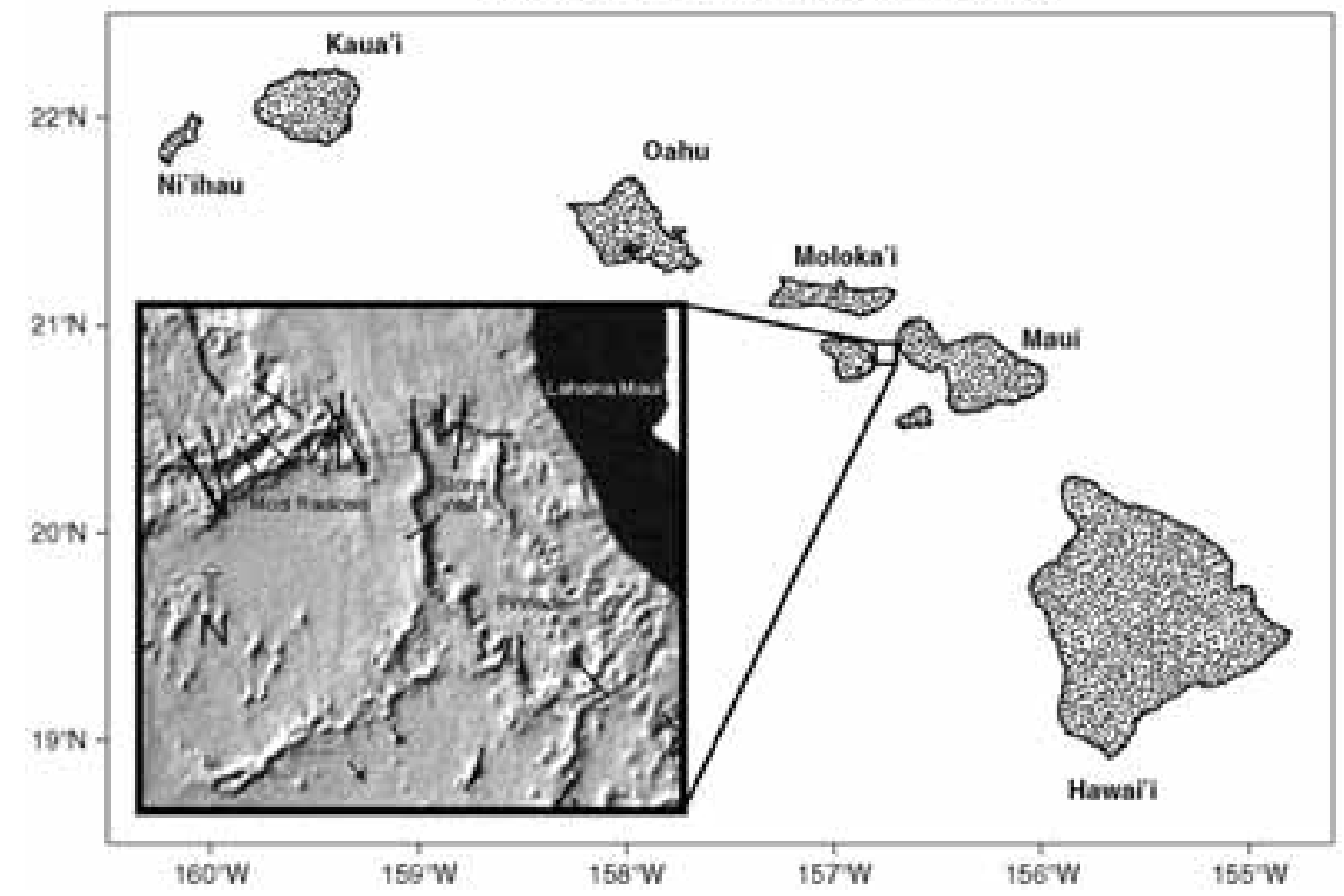

FIGURE 1. Map of survey areas. Inset is the channel bathymetry with track lines of the remote camera surveys.

traveled through the screen; resident fishes remained with a tree during the 3 -min segment. The fish assemblage derived from the archival camera was then compared with the fish data collected in the same area by divers.

\section{Analysis}

The unbalanced design and nonnormal data limited this analysis to nonparametric techniques. The sample size permitted detection of medium effects for the coral data and large effects for the fish data at a power of 0.80 (Cohen 1977). Comparisons between the three dive sites relied on a Kuskal-Wallis test for tree size structure and a Friedman test to assess differences in the rank of fish taxa. For the diver observations, the data were analyzed for fish species abundance, fish association with black coral trees, and correlations between fishes and tree height. The daytime segment of the archival video was analyzed for the overall fish number and species richness. Taxa that were observed in both the archival and diver surveys were compared using a Wilcoxon test for two related samples.

\section{RESULTS}

\section{Camera Transects}

The ship-based remote camera inspected tracts of bottom on 22 transects. Black coral was seen only on high-relief features and on the slopes of pinnacles. However, many of these relief features were devoid of coral. Three sites were selected to be surveyed by divers (Figure 1). Local coral divers refer to the first dive site ( $n=$ two dives) as "most radicals". Of the three it was the most exposed to prevailing winds because of its location in the center of the channel. The second 
TABLE 1

Mean, Standard Deviation, and Range of Black Cora Tree Height at the Three Study Sites

\begin{tabular}{lrrr}
\hline \hline Survey Site & Mean $(\mathrm{cm})$ & $(n)$ & Range $(\mathrm{cm})$ \\
\hline Stonewalls & $76.2 \pm 30.9$ & 71 & $20.3-165.1$ \\
Most radicals & $62.2 \pm 25.6$ & 34 & $28.5-121.9$ \\
Pinnacle & $100.3 \pm 43.8$ & 40 & $30.5-182.9$ \\
\hline
\end{tabular}

site $(n=$ seven dives $)$ was closer to Lahaina, Maui, and more protected from the wind. At this site, called "stonewalls" corals grew along the southern wall of a large solution basin. The third site ( $n=$ five dives) was an unnamed pinnacle to the east rising from the center of the solution basin; we refer to this site as "the pinnacle".

\section{Coral Size Structure}

Divers measured 145 black coral trees from the three sites (Table 1). The majority of these were $A$. dichtoma and $A$. grandis, with only two $A$. ulex observed. Trees averaged 76 $\mathrm{cm}$ in height with a range from 20 to $182 \mathrm{~cm}$. Many of the black coral bases were composed of multiple stems, so all the measurements reflect the thickest stem found on the base of a given tree. Figure 2 presents the size structure of the coral measured with reference lines for the two minimum heights $(1.22 / 0.9$ $\mathrm{m})$ and stem diameters $(2.54 / 1.9 \mathrm{~cm})$ required for legal harvest. There was a weak positive correlation of tree height with depth (Spearman's $\left.r_{s}=0.169, P<0.05\right)$. The differences in the mean sizes of trees between sites were nearly significant (Kruskal-Wallis $\chi^{2}=5.72$, $P<0.057)$. The tallest trees were found at the pinnacle, and the shortest trees were found at most radicals.

\section{Fish Assemblages}

Video observations made on 208 black coral trees found 11 trees dead and three encrusted with the invasive octocoral Carijoa riisei. Only $46 \%$ of the 208 trees surveyed had fishes associated with them. All of those trees were alive except two. Forty species of fishes were documented on these dives and are listed in Table 2. Ninety-five percent of these species are known to occur commonly in shallow water $(<60 \mathrm{ft}[20 \mathrm{~m}])$. The rank of the top 20 taxa ( $n>4$ individuals per taxon) did not differ significantly between the three sites (Friedman $\chi^{2}=3.556, P=0.169$ ). A marginal positive correlation of fish density with tree height (Spearman's $r_{s}=0.246$, $P<0.05)$ occurred when trees were pooled across the three sites.

\section{Fish Use of Corals as Shelter}

Tree height is a good representation for overall cover afforded by a tree: taller trees were wider, whereas shorter trees were thinner. The overall number of fishes that evaded the divers by using a coral tree as shelter significantly increased with the height of the tree $\left(r_{s}=0.323, P<0.01\right)$. Pooling all species that were observed to use black coral trees at least part of the time totaled $60 \%$ of the fish assemblage. Only four of the top 20 species consistently sought refuge $(>75 \%$ of the time) among the black coral tree branches (Aulostomus chinensis, $n=6$ fish; Canthigaster jactator, $n=7$ fish; Centropyge potteri, $n=41$ fish; Dascyllus albisella, $n=112$ fish); the rest of the taxa were prone to flee. Of the remaining 16 species, six tended to be large fishes, often in schools, that always fled from the divers and did not seek cover in the trees, and the rest of the species used the trees for cover only part of the time.

\section{Archival Video}

The archival camera recorded 91 video segments and documented 426 fish sightings comprising 38 species over 3 days and 2 nights. During daylight hours, visibility was out to $10 \mathrm{~m}$; at night it was limited to $1.5 \mathrm{~m}$. Ninety percent of the fishes were transitory (moved through camera view), and the rest were residential to the three trees in the camera's view.

The mean number of fishes by taxa seen in coral trees did not differ significantly (Wil- 


\section{Height - base relationship}

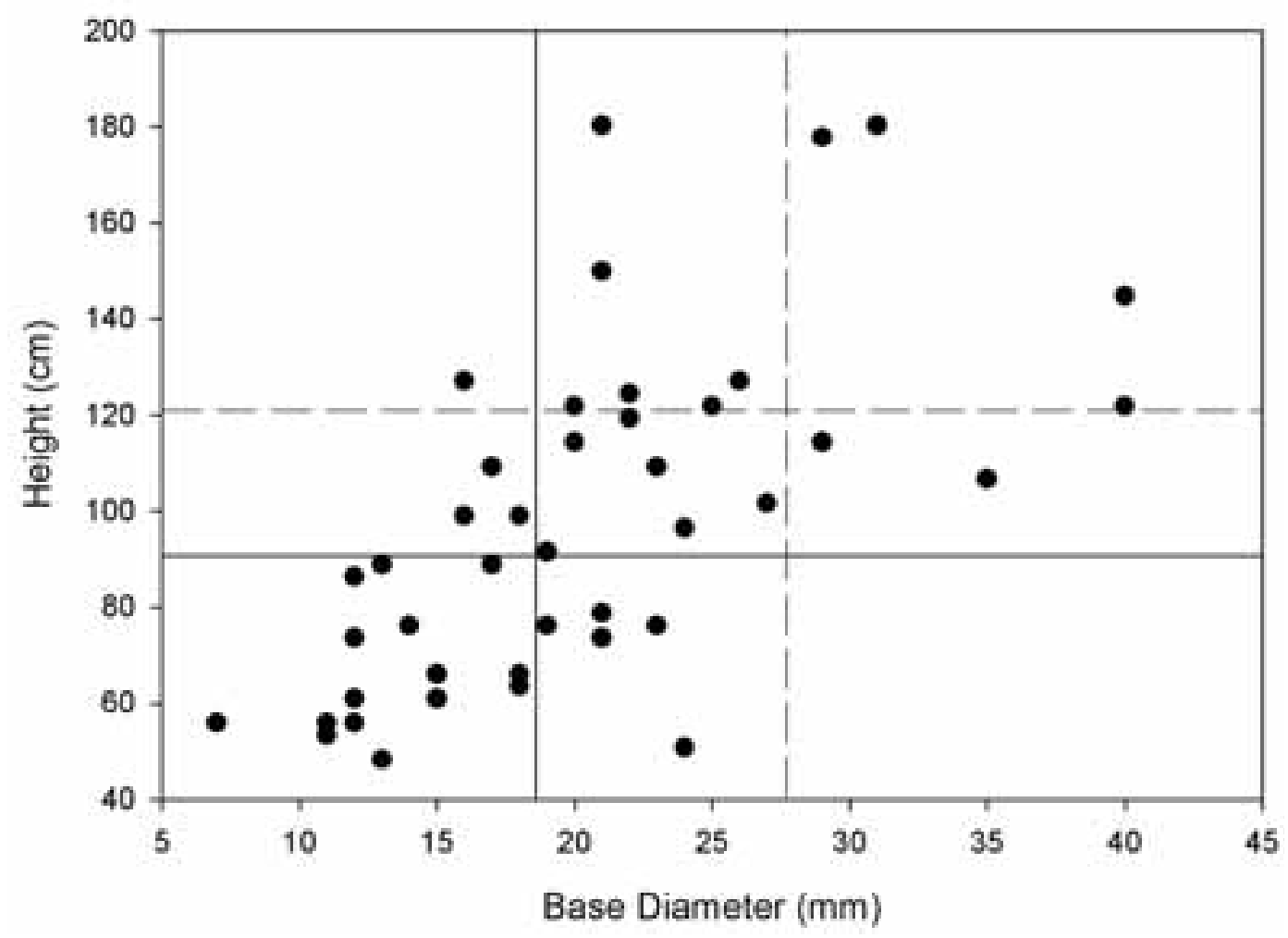

Figure 2. Size structure of the coral measured. Dashed reference lines are the minimum height and stem diameter required for legal harvest by new harvesters entering the fishery, and solid reference lines are the minimum height and stem diameter required for legal harvest by harvesters participating for $5 \mathrm{yr}$ previous to April 2002.

coxon test $Z=-0.594, P=0.552$ ) between diver surveys and the sampling of the archival camera, suggesting that both observational methods achieve similar results. The wideranging movements of the fish assemblages from tree to tree resulted in homogeneous counts whether the survey was of many trees (Figure $3, t o p$ ) or a few trees surveyed many times (Figure 3, both). During the day 5 species kept within $1 \mathrm{~m}$ of the tree and used it for cover. These species were Dascyllus albisella, Centropyge potteri, Forcipiger flavissimus, Aulostomus chinensis, and Canthigaster jactator. Only Dascyllus albisella and Centropyge potteri appeared to be resident to specific trees. Forcipiger flavissimus and Canthigaster jactator appeared to use the trees in transit but did not appear to be residential to a specific tree. Forcipiger flavissimus was also observed foraging among the tree branches. Aulostomus chinensis was seen to orient within the tree branches and strike at potential prey. During the night, only two species were observed using the trees: Sargocentron sp. and Heniochus diphereutes. Sargocentron sp. appeared to be using the trees for cover as it foraged near the bottom. Heniochus diphereutes used the tree for cover at night and during the day foraged in the water column far above the bottom. During one of the night video segments a large piscivore $(\sim 50 \mathrm{~cm})$, Caranx ignobilis, was recorded passing through the patch of 
TABLE 2

Rank of All Fish Taxa Encountered, Mean Number of Individuals per Tree, Whether Fishes Were Present in Diver Survey Only (D) or Both Diver and Camera Survey (D/C), and Percentage of Times Taxa Evaded Divers Using the Trees as Shelter

\begin{tabular}{|c|c|c|c|c|}
\hline Species & No. of Trees & Mean of Fishes per Tree & Diver/Camera & Sheltered $\%^{a}$ \\
\hline Dascyllus albisella & 52 & 2.154 & $\mathrm{D} / \mathrm{C}$ & 77 \\
\hline Chaetodon miliaris & 28 & 5.536 & $\mathrm{D} / \mathrm{C}$ & 45 \\
\hline Centropyge potteri & 27 & 1.519 & $\mathrm{D} / \mathrm{C}$ & 93 \\
\hline Forcipiger flavissimus & 25 & 1.960 & $\mathrm{D} / \mathrm{C}$ & 61 \\
\hline Ctenochaetus strigosus & 22 & 1.727 & $\mathrm{D} / \mathrm{C}$ & 29 \\
\hline Parupeneus multifasciatus & 18 & 2.889 & $\mathrm{D} / \mathrm{C}$ & 4 \\
\hline Chaetodon kleinii & 18 & 1.556 & $\mathrm{D} / \mathrm{C}$ & 46 \\
\hline Scaridae & 11 & 4.091 & $\mathrm{D} / \mathrm{C}$ & 3 \\
\hline Acanthurus nigrofuscus & 10 & 1.900 & $\mathrm{D} / \mathrm{C}$ & 37 \\
\hline Chromis hanui & 8 & 3.625 & $\mathrm{D}$ & 45 \\
\hline Chromis verater & 8 & 2.500 & $\mathrm{D}$ & 35 \\
\hline Zanclus cornutus & 8 & 1.875 & $\mathrm{D} / \mathrm{C}$ & 0 \\
\hline Zebrasoma flavescens & 7 & 1.571 & $\mathrm{D}$ & 9 \\
\hline Canthigaster jactator & 7 & 1.000 & $\mathrm{D} / \mathrm{C}$ & 100 \\
\hline Sargocentron sp. & 6 & 1.167 & $\mathrm{D} / \mathrm{C}$ & 43 \\
\hline Aulostomus chinensis & 6 & 1.000 & $\mathrm{D} / \mathrm{C}$ & 83 \\
\hline Chaetodon multicinctus & 5 & 1.400 & $\mathrm{D} / \mathrm{C}$ & 0 \\
\hline Bodianus bilunulatus & 5 & 1.200 & $\mathrm{D} / \mathrm{C}$ & 0 \\
\hline Acanthurus olivaceus & 4 & 2.750 & $\mathrm{D}$ & 0 \\
\hline Sufflamen bursa & 4 & 1.250 & $\mathrm{D} / \mathrm{C}$ & 0 \\
\hline Chromis ovalis & 3 & 2.333 & $\mathrm{D}$ & NA \\
\hline Parupeneus pleurostigma & 3 & 1.000 & $\mathrm{D}$ & NA \\
\hline Chaetodon lunula & 2 & 1.500 & $\mathrm{D} / \mathrm{C}$ & NA \\
\hline Labroides phthirophagus & 2 & 1.500 & $\mathrm{D}$ & NA \\
\hline Apogonidae & 2 & 1.000 & $\mathrm{D}$ & NA \\
\hline Cephalopholis argus & 2 & 1.000 & $\mathrm{D} / \mathrm{C}$ & NA \\
\hline Oxycirrbites typus & 2 & 1.000 & $\mathrm{D}$ & NA \\
\hline Thalassoma duperrey & 2 & 1.000 & $\mathrm{D} / \mathrm{C}$ & NA \\
\hline Mulloidichtbys flavolineatus & 1 & 26.000 & $\mathrm{D}$ & NA \\
\hline Anampses cuvier & 1 & 2.000 & $\mathrm{D}$ & NA \\
\hline Arotbron meleagris & 1 & 2.000 & $\mathrm{D}$ & NA \\
\hline Heniochus diphreutes & 1 & 2.000 & $\mathrm{D} / \mathrm{C}$ & NA \\
\hline Anampses chrysocephalus & 1 & 1.000 & $\mathrm{D}$ & NA \\
\hline Calotomus sp. & 1 & 1.000 & $\mathrm{D}$ & NA \\
\hline Chaetodon fremblii & 1 & 1.000 & $\mathrm{D}$ & NA \\
\hline Chromis agilis & 1 & 1.000 & $\mathrm{D}$ & NA \\
\hline Desmobolocanthus arcuatus & 1 & 1.000 & $\mathrm{D} / \mathrm{C}$ & NA \\
\hline Lutjanus kasmira & 1 & 1.000 & $\mathrm{D} / \mathrm{C}$ & NA \\
\hline Malacantbus brevirostris & 1 & 1.000 & $\mathrm{D}$ & NA \\
\hline Pseudanthias hawaiiensis & 1 & 1.000 & $\mathrm{D}$ & NA \\
\hline
\end{tabular}

${ }^{a} \mathrm{NA}$ is for fish numbers too few ( $n<4$ fishes) to count relative fidelity.

corals. The presence of the predator did not cause the resident fishes to flee the trees.

Tidal cycles in water flow were clearly evident on the video from the speed of branch movement and passing particulates. Effects of changing water flow on these fish taxa were noticeable. During periods of high flow, Dascyllus albisella was seen closer to the trees, and planktivores such as Chaetodon miliaris and Heniochus diphereutes were not seen in the water column. During periods of low flow, Dascyllus albisella ventured farther into the water column, and Cbaetodon miliaris and Heniochus diphereutes were seen periodically swimming through the water column above the trees. 


\section{Diver Observation}

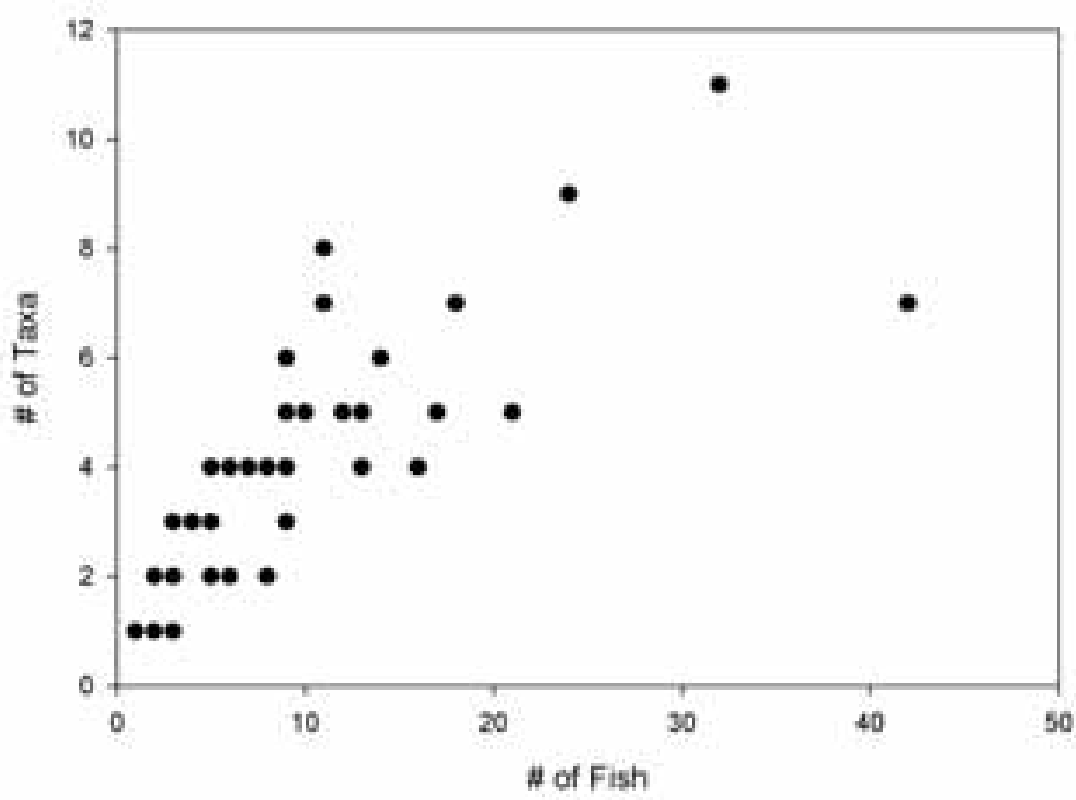

Video Observation

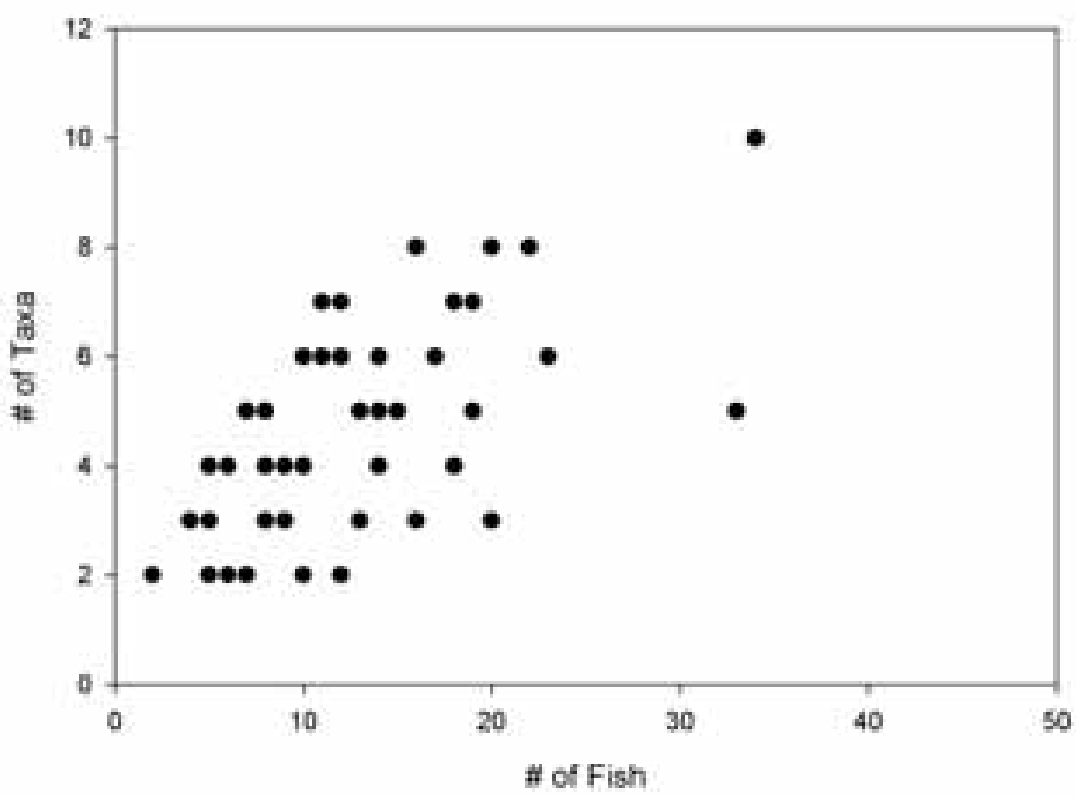

Figure 3. Distribution of taxa and fishes between diver observations (top) and remote camera observations (bottom). 


\section{DISCUSSION}

\section{Coral Size Structure}

The size structure of a pristine black coral bed and its associated fish assemblage is unknown. In Hawai' $i$, and most other locations, researchers come to observe the beds after fishermen have been harvesting coral trees for decades. Grigg (2004) noted that the biomass of black corals had decreased by $25 \%$ from 1976 preexploitation levels, and he attributed this to harvesting pressure. The fraction of trees within harvestable size reported in our study ranged from 30 to $60 \%$ (Figure 2) depending on which harvest limits were applied. In addition we expected our estimates to be higher than those of Grigg (2004) because of differences in survey and measurement technique. We surveyed 12.5 $\mathrm{km}$ of bottom with the remote camera and selected the sites with the most developed coral patches, so our size structure estimates are likely to be inflated. Grigg's estimates are based solely on tree heights, whereas ours include base diameter, which can double the allowable take under the varying harvest guidelines of height $(1.2 / 0.9 \mathrm{~m})$ or base diameter $(2.5 / 1.9 \mathrm{~cm})$. Even the heights of the two surveys are likely to be different because Grigg used a laser scale projected from a submersible to estimate tree height $( \pm 15 \mathrm{~cm})$, whereas our divers measured the tree height by stretching a flexible tape from the base of the tree to its highest point and used calipers to measure each tree's base diameter. The laser scale likely reflects the tree's natural height as it stands in the field, and the diver measurements represent the longest axis of the tree. Grigg's height measurement is probably what the coral divers consider when harvesting, and ours is what would be measured once the coral was brought to the surface.

The borderline difference in the tree height between most radicals and the other two sites is unexplained. Its exposed location in the middle of the channel may result in stronger currents truncating the size structure of those coral trees. Another possibility is that the Maui divers who harvest corals report that they rotate the areas they work in (Robin Lee, pers. comm.) and that most radicals may be the most recently harvested area. It is not known how often areas are rotated, but with an estimated growth rate of $6.42 \mathrm{~cm} / \mathrm{yr}$ (Grigg 2001), it would take $19 \mathrm{yr}$ for a black coral to reach harvestable size $(1.2 \mathrm{~m})$ in an area being rotated.

Grigg's (2004) surveys of the channel waters used submersibles to go deeper than the coral divers and discovered the invasive octocoral Carajoa riisei as a dominant bottom cover that is overgrowing black coral colonies. Our surveys of shallower depths found only three trees with Carajoa riisei and these were all dead $(27 \%$ of total dead trees encountered). Carajoa riisei was seen in other areas growing predominately under ledges in the black coral beds; this was also reported by Grigg (2004).

\section{Fish Assemblage}

Fish diversity documented in these coral beds is consistent with the limited fish data available for these depths in this region. Fish surveys (Moffitt et al. 1989) conducted $75 \mathrm{~km}$ west of the our study site to monitor fish assemblages around artificial reefs between 61 and $117 \mathrm{~m}$ deep afford our best comparison. These surveys $(n=18)$ were conducted over the course of $3 \mathrm{yr}$ monitoring the recruitment and colonization of fishes to artificial structures, most of which were roughly consistent in height $(1.5 \mathrm{~m})$ with black coral trees. At the apex of species richness, 62 species were documented. Twenty-one of these species were seen in the Maui coral beds; however, the abundance of snappers and jacks was missing. The other missing taxa were typically associated with deeper depths, including species such as Parapercis roseoviridis, Holanthias fuscipinnus, Brotula multibarbata, and Evistas typus. This suggests that the Lahaina Roads black coral bed community has more in common with shallower reef systems than with deep-slope communities.

Few fish taxa are associated exclusively with black coral trees. Fishes, such as Oxycirrbites typus, are the best example of a nearexclusive association with black coral (Tinker 1978); they were not seen outside the corals. However even with the abundance of black 
coral at these sites relatively few $O$. typus were encountered, and some species that we expected to see were absent. Chaetodon tinkeri, which is commonly thought to be associated with black coral (Tinker 1978), was never observed. Also largely absent were species of Anthias, which are expected to be in abundance at these depths and in high-flow environments (Myers 1989). The only members of this group we encountered were a pair of Psuedanthias hawaiiensis. Because these fish types are not prone to capture on hook and line and the black coral beds are located in high currents at deep depths, there is no reason to think that these fish types were removed. These species are sought by the aquarium trade. Consulting the state records of aquarium landings for the channel waters off Maui indicated that few fishes have been collected from the region (State of Hawai' $i$ Department of Land and Natural Resources C-6 data). In the 10-yr span of 1991 to 2001 the aquarium landings reported that $123 \mathrm{An}$ thias sp., 12 O. typus, and fewer than five $C$. tinkeri were collected (commercial fishing statistical charts 300, 301, 320, and 321). Even assuming that these catch reports underreport, these numbers are extremely small for that period of time. Checking with an aquarium fish wholesaler (Paul Williams at Pisces Pacifica) revealed no evidence of an appreciable trade in C. tinkeri from Maui.

\section{Fish Association with Coral}

The majority of fishes were seen orienting in relation to the black coral trees or using them for cover at least part of the time. Larger trees do generally support more fishes, but this effect does not dictate the structure of the fish community. The positive correlation between fishes and tree height was dependent on pooled data and was lost when the analysis was run for the three individual sites. The fishes used the shelter of the coral trees interchangeably with other abiotic relief sources. The archival video provided useful insight to the prolonged movements of a fish assemblage around patches of coral trees. The few species that stayed with the trees during the diver surveys were the same species that were residents to the coral trees in the archival video. Even without the commotion of scuba diving, most species were seen to move from tree to tree with brief stops in their movements. Fishes at the pinnacle site are a captive community, bound to it by the habitat it provides in an otherwise barren sand plain. The $90+$ coral trees on its flanks provide the only appreciable shelter, and the fish assemblages appear to range widely from tree patch to tree patch.

Black coral trees certainly provide cover for fishes and improve their ability to forage higher in the water column. If the fishes were deprived of the trees, they would make use of abiotic sources of cover. However, at the sites with few sources of relief such as the slope of the pinnacle, removal of the coral trees (the only cover available) is likely to impact the fish assemblage. Black coral trees contribute to the fish community in a general sense by enhancing the vertical aspects of the deep reef and perhaps improving movement conditions for reef fishes.

\section{CONCLUSIONS}

Fishes make use of the relief and branches of black coral trees as a place to orient from the bottom and use as shelter if needed. No fish species were identified that resided exclusively within the black corals. There is a marginal correlation between the height of a black coral tree and the number of fishes that associate with it. Despite the general use of the trees by a majority of fishes, few species took shelter in the trees when confronted by an approaching diver. Observations made from an archival camera indicate that in the absence of divers the same few species composed persistent stable fish assemblages associated with specific coral trees. This includes cryptic species using them for cover during the day and some conspicuous midwater species relying on them at night.

\section{ACKNOWLEDGMENTS}

We thank the following divers who worked on this specialized deep diving project: Richard Pyle, John Earle, John Rooney, Dave 
Pence, Mike Sawyer, and Brian Greene; the officers and crew of the NOAA ship Townsend Cromwell for their excellent seamanship and dive support; and Paul Williams at Pisces Pacifica and Robin Lee for their expertise. We also thank Robert Moffitt and Robert Schroeder for their review of this paper.

\section{Literature Cited}

Auster, P. J., R. J. Malatesta, R. W. Langton, L. Watling, P. C. Valentine, C. Lee, S. Donaldson, E. W. Langton, A. N. Shepard, and I. G. Babb. 1996. The impacts of mobile fishing gear on seafloor habitats in the Gulf of Maine (Northwest Atlantic): Implications for conservation of fish populations. Rev. Fish. Sci. 4 (2): 185-202.

Cohen, J. 1977. Statistical power analysis for the behavioral sciences. 2nd ed. Lawrence Erlbaum Associates, Hillsdale, New Jersey.

Freese, L., P. J. Auster, J. Heifetz, and B. L. Wing. 1999. Effects of trawling on seafloor habitat and associated invertebrate taxa in the Gulf of Alaska. Mar. Ecol. Prog. Ser. 182:119-126.

Gonzalez, E., B. Guitart, and M. Garcia. 1997. Sown black coral Antipathes sp. in the Cuban southwest. Page 73 in Proceedings, 5th Congress on Marine Science. MarCuba '00, Havana, Cuba.

Grigg, R. W. 1964. A contribution to the biology and ecology of the black coral Antipathes grandis in Hawaii. M.S. thesis,
University of Hawai'i at Mānoa, Honolulu.

1965. Ecological studies of black coral in Hawaii. Pac. Sci. 19:244-260.

. 1993. Precious coral fisheries of Hawaii and the U.S. Pacific Islands. Mar. Fish. Rev. 55 (2): 50-60.

- 2001. Black coral: History of a sustainable fishery in Hawai'i. Pac. Sci. 55:291-299.

2004. Harvesting impacts and invasion by an alien species decrease estimates of black coral yield off Maui, Hawai'i. Pac. Sci. 58:1-8.

Moffitt, R. B., F. A. Parrish, and J. J. Polovina. 1989. Community structure, biomass and productivity of deepwater artificial reefs in Hawaii. Bull. Mar. Sci. 44 (2): 616-630.

Montgomery, A. D. 2002. The feasibility of transplanting black coral (Order Antipatharia). Hydrobiologia 471:157-164.

Myers, R. F. 1989. Micronesian reef fishes: A practical guide to the identification of the coral reef fishes of the tropical central and western Pacific. Coral Graphics, Barrigada, Guam.

Romero, X. M. 1997. Ecuador's vanishing black corals. Aquaticus: J. Shedd Aquarium 26 (2): 21-25.

Tinker, S. W. 1978. Fishes of Hawaii: A handbook of the marine fishes of Hawaii and the central Pacific Ocean. Hawaiian Service Inc., Honolulu, Hawai'i. 